\title{
THE APPROACHES OF THE ROMANIAN AUTHORS REGARDING THE CSR CONCEPT
}

\author{
Nicoleta-Daniela Milu \\ Doctoral School of Economic Sciences and Business Administration, West University of \\ Timisoara, Romania \\ nicoleta.milu@e-uvt.ro
}

\begin{abstract}
In Romania, large companies, most of which are multinationals, have made significant progress in integrating the concept of corporate social responsibility (CSR) into their activity. The concept of CSR in small and medium-sized companies is still in the early stages of reporting, but with great development prospects. Romanian companies have gradually begun to develop their own culture in terms of social responsibility. The main objective of this article is to analyze how Romanian authors approach CSR theories in their research. The CSR action is seen by the authors as an interdependent relationship between corporations and society. Social requirements are generally considered to be a way in which society interacts with the business environment and gives it a certain legitimacy and prestige. Given that the history of the concept of CSR is long and diverse, I must emphasize that this article focuses on the publications of Romanian authors who based their work on a theory of CSR, providing an original perspective and understanding of the concept of CSR. The research methodology approached involves analysis and synthesis appeal. The study shows that integrative theories are the most common, based on the papers of Romanian authors regarding the concept of CSR. Most articles are based on the idea that the business depends on society to continue its activity and to develop, there is an interdependent relationship between the company and society.
\end{abstract}

Keywords: CSR theories, company, society, Romanian authors

JEL classification: M14; M40; M49.

\section{Introduction}

In the literature there are different perspectives on the concept of CSR both theoretical and practical, from different points of view regarding the role of corporations in society.

The researchers tried to define the concept of CSR using various theories such as stakeholders, integrative, instrumental, political, ethical and legitimacy theories.

Values and norms differ in their form between cultural spheres, countries and political systems and can be changed over time. The problem of how values and norms are formed is the key to understanding current developments and changes in social relations.

The main purpose of this article is to identify the theories underlying the CSR and to approach these theories of the various Romanian authors in their research in the period 2018-2019.

The methodology used in the writing of the paper starts with the analysis of the literature, and will be synthesized in the second part of the paper.

The result of the research shows that most articles of Romanian authors are based on integrative theories, which largely recognize an interdependent relationship between corporations and society.

The main contribution of this paper is a review of the most representative articles indexed in the recognized database of Web of Science in the period 2018-2019, and at the same time 
seeing what would be the most representative theory on which the paper is based. Each author presents in his article the concept of CSR, but viewed from different perspectives, they constraining their work on different theories. The result shows that most of the works of Romanian authors are based on the integrative theory, so that the whole paper is built on an interdependent relationship between company and society.

\section{Theoretical considerations}

Corporate social responsibility (CSR) has been applied in the Romanian economic environment quite recently, taking over and developing practices and activities in that sphere to allow multinational partnerships.

The opinion of the authors Obrad et al (2011) regarding CSR integration in Romania is that corporate social responsibility actions have diversified and gradually became professionalized by the existence of multinational companies in the domestic economy, becoming in many cases, "a constant, integrated concern in their development strategy".

At international level, Garriga and Melé (2004) present a taxonomy of the main theories and approaches of CSR. As a starting point for their classification, the authors suppose that the most important theories and approaches of CSR have four dimensions, regarding profits, political performances, social requirements and ethical values. This hypothesis allows the authors to classify CSR theories into four groups: instrumental, political, integrative and ethical theories.

Instrumental CSR theories represent the traditional view on corporate social responsibility, in which the role of the state and the business environment are clearly differentiated.

The responsible behavior of companies supports achievement their goal of profitability, while their financial strength allows the fulfillment of CSR practices. CSR actions are based on financial resources, to satisfy the interests of those involved, the company and society, as well as on the dynamics of power between these parties (Siminica et al., 2019).

Theories in this category support the hypothesis that the sole responsibility of corporations is to generate economic benefits (Garriga and Mele', 2004).

Scherer and Palazzo (2011) are of the opinion that CSR theories of political nature assume that companies assume a political role in addressing the problems caused by the insufficient state governance and maintaining certain social and environmental standards.

This group of CSR theories and approaches focuses on the interactions and connections between companies and society and at the same time its position on business and its inherent responsibility.

Integrative CSR theories largely recognize an interdependent relationship between corporations and society. These theories focus on integrating the expectations of stakeholders in corporate operations (Geva, 2008).

The company must follow expectations regarding the business environment: economic, legal, ethical and discretionary. 


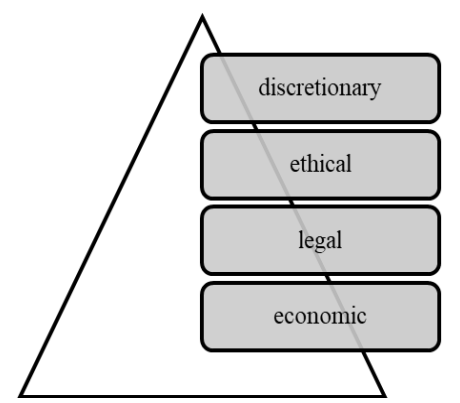

Figure 1: CSR from the perspective of society's expectations

Source: Carroll, A.B., 1991. The pyramid of corporate social responsibility: toward the moral management of organizational stakeholders, Business Horizons, 34(4), pp.39-48;

Carroll (1991) was the one who created the CSR pyramid (Figure no. 1) which ranks the social responsibility of companies on four levels, from the obligation to be profitable (economic level), continuing with the obligation to respect the law (legal level), followed by the obligation of the company to do what is right and fair (ethical level) and ending with the recommendation that the company contribute resources to the welfare of the community (discretionary level).

According to Friedman (1970), the normative theory of stakeholders on ethics and morality offers an objective for CSR literature, defending the ethical premise of companies that behave well from a societal perspective.

Companies can have a competitive advantage by communicating corporate values well from a societal perspective. These values must be part of the company's identity for the concept of CSR to be fully integrated (Farcane et al., 2019).

Recent research (Obrad and Gherhes, 2018) suggests that the concept of sustainability includes ethical issues that should guide the company towards a long-term vision. Ethical responsibility includes activities that are not necessarily presented in laws, but nevertheless society expects a business to respect the members of a society and prevent a negative impact on it.

Fernando and Lawrence (2014) believe that at the basis of CSR, there are two other theories: stakeholder theory and legitimacy theory. The stakeholder theory is closely linked to the creation of value for the entity and for the stakeholders.

Dumitru et al. (2017) studied the relationship between value creation and stakeholder theory through integrated reporting and they come to the conclusion that communication is an important element for value creation, and that there are discrepancies in the content of information reports that address different categories of stakeholders.

Kerscher and Schäfers (2015) is of the opinion that an essential condition for the theory of legitimacy is the concept of the social contract which claims that any organization within the society operates through a social contract. Legitimacy occurs when a value system of entities is consistent with the value system of the community to which the organization belongs (Stoica et al., 2019).

In contrast to classical economic theories, a corporation must seek societal approval of its operations and revenues to ensure long-term survival.

\section{Research methodology}

The research methodology of this paper starts with a first stage of scientific documentation about CSR theories. CSR research continues with the analysis of the content of 20 articles most relevant published in the period 2018-2019 in the Web of Science following key words: 
CSR (Corporate Social Responsibility), Romania (Romanian), sustainability. The methodology approached involves analysis and synthesis appeal.

The aim of the research was to identify the theories that underlie the research of the Romanian authors.

\section{The approaches of the Romanian authors regarding the concept of CSR}

In table no. 1 are synthesized the ideas of the Romanian authors who approached in their research the concept of CSR and the relationship between company and society, with reference to the CSR theories analyzed in the first part of the paper.

The articles were chosen from those written in the period 2018-2019 in the Web of Science following key words: CSR (Corporate Social Responsibility), Romania (Romanian), sustainability. This short period of time was chosen because starting with 2018 , in Romania companies with more than 500 employees are required to report non-financial statements related to 2017. In this way it is possible to observe how the authors perceive the concept of CSR and on what theory they are based.

Each analyzed article may be based on several theories from those presented above, but we have selected the most representative theory for that paper.

Tabel 1. The approaches of the Romanian authors regarding the CSR concept

\begin{tabular}{|c|c|c|}
\hline Authors & Main idea & CSR theories \\
\hline $\begin{array}{l}\text { Androniceanu } \\
\text { A. }(2019)\end{array}$ & $\begin{array}{l}\text {-managers believe that limited financial resources } \\
\text { do not allow them to develop CSR actions; they } \\
\text { would like to take CSR actions only if its bring } \\
\text { future benefits; }\end{array}$ & instrumental theorie \\
\hline $\begin{array}{l}\text { Bucur et al. } \\
(2019)\end{array}$ & $\begin{array}{l}\text {-companies activities have financial, } \\
\text { environmental and social consequences; CSR } \\
\text { represents an interdependent relationship } \\
\text { between the company and the society; }\end{array}$ & integrative theories \\
\hline $\begin{array}{l}\text { Burlea- } \\
\text { Schiopoiu et } \\
\text { al. (2019) }\end{array}$ & $\begin{array}{l}\text {-CSR is the way in which an organization acts } \\
\text { voluntarily to meet social and environmental } \\
\text { objectives in its daily operations and, at the same } \\
\text { time, to generate a profit for the company; }\end{array}$ & $\begin{array}{l}\text { integrative } \\
\text { theories }\end{array}$ \\
\hline $\begin{array}{l}\text { Cioca et al. } \\
(2019)\end{array}$ & $\begin{array}{l}\text {-benefits of CSR can be found in economic, } \\
\text { social, and environmental areas; sustainability } \\
\text { exists as long as there are requests from } \\
\text { employees, laws regulations, or financial benefits; }\end{array}$ & $\begin{array}{l}\text { integrative } \\
\text { theories }\end{array}$ \\
\hline $\begin{array}{l}\text { Cosmulese et } \\
\text { al. (2019) }\end{array}$ & $\begin{array}{l}\text {-CSR is a means of communication to support the } \\
\text { interests of stakeholders; the ability of such } \\
\text { companies are to satisfy the stakeholders; }\end{array}$ & stakeholders theory \\
\hline $\begin{array}{l}\text { Cristache et } \\
\text { al. (2019) }\end{array}$ & $\begin{array}{l}\text {-by including the specific dimensions of a code of } \\
\text { social responsibility in the strategies of the } \\
\text { companies, it would contribute to the increase of } \\
\text { their long-term performance; }\end{array}$ & legitimacy theory \\
\hline $\begin{array}{l}\text { Dinu and } \\
\text { Bunea (2019) }\end{array}$ & $\begin{array}{l}\text {-sustainable companies are the ones that } \\
\text { anticipate future needs of society and } \\
\text { they adapt their business according to their needs } \\
\text { to their needs; }\end{array}$ & $\begin{array}{l}\text { integrative } \\
\text { theories }\end{array}$ \\
\hline
\end{tabular}




\begin{tabular}{|c|c|c|}
\hline $\begin{array}{l}\text { Farcane et al. } \\
(2019)\end{array}$ & $\begin{array}{l}\text {-CSR represents the relationship between } \\
\text { business and society that is incorporated with } \\
\text { ethical values; the values created must be among } \\
\text { the values of the companies; }\end{array}$ & ethical theories \\
\hline $\begin{array}{l}\text { Hategan et al. } \\
(2018)\end{array}$ & $\begin{array}{l}\text {-CSR is a key concept for sustainability and } \\
\text { managers should be aware of it that reporting } \\
\text { activities brings benefits to the company and } \\
\text { stakeholders; }\end{array}$ & $\begin{array}{l}\text { stakeholders } \\
\text { theory }\end{array}$ \\
\hline $\begin{array}{l}\text { Hategan et al. } \\
(2019)\end{array}$ & $\begin{array}{l}\text {-CSR is closely linked to the politics and } \\
\text { legislation of each country, the content of non- } \\
\text { financial reports depends on government policies } \\
\text { and cultures; }\end{array}$ & political theories \\
\hline $\begin{array}{l}\text { Obrad et al. } \\
(2018)\end{array}$ & $\begin{array}{l}\text {-CSR represents the achievement of economic } \\
\text { success in an ethical manner; }\end{array}$ & ethical theories \\
\hline $\begin{array}{l}\text { Marin- } \\
\text { Pantelescu et } \\
\text { al. (2019) }\end{array}$ & $\begin{array}{l}\text {-CSR represents an approach of running and } \\
\text { managing businesses with the conformity of } \\
\text { protecting the environment, serving the common } \\
\text { good of the company and society; }\end{array}$ & $\begin{array}{l}\text { integrative } \\
\text { theories }\end{array}$ \\
\hline $\begin{array}{l}\text { Saveanu et al. } \\
\text { (2019) }\end{array}$ & $\begin{array}{l}\text {-the attitude of the managers regarding the } \\
\text { welfare of the company, the attitude of the } \\
\text { company towards the CSR; }\end{array}$ & $\begin{array}{l}\text { integrative } \\
\text { theories }\end{array}$ \\
\hline $\begin{array}{l}\text { Siminica et al. } \\
(2019)\end{array}$ & $\begin{array}{l}\text {-the concept CSR is a strategic tool with which } \\
\text { companies are trying to maximize financial } \\
\text { performance concomitant with social and } \\
\text { environmental aspects; }\end{array}$ & $\begin{array}{l}\text { instrumental } \\
\text { theories }\end{array}$ \\
\hline $\begin{array}{l}\text { Simionescu } \\
\text { and } \\
\text { Dumitrescu } \\
(2018)\end{array}$ & $\begin{array}{l}\text {-CSR has an active impact on the stakeholders } \\
\text { and supports the voluntary actions, the } \\
\text { community, these being carried out ethically and } \\
\text { economically; }\end{array}$ & $\begin{array}{l}\text { integrative } \\
\text { theories }\end{array}$ \\
\hline $\begin{array}{l}\text { Socoliuc et al. } \\
\text { (2018) }\end{array}$ & $\begin{array}{l}\text { - CSR means having ethical and economic } \\
\text { motivations than to immediately receive a positive } \\
\text { response from stakeholders; }\end{array}$ & $\begin{array}{l}\text { integrative } \\
\text { theories }\end{array}$ \\
\hline $\begin{array}{l}\text { Stoica et al. } \\
(2019)\end{array}$ & $\begin{array}{l}\text {-in order to attain legitimacy, corporations have } \\
\text { become more transparent and involved in social } \\
\text { and environmental issues; }\end{array}$ & legitimacy theory \\
\hline $\begin{array}{l}\text { Voinea et al. } \\
(2019)\end{array}$ & $\begin{array}{l}\text {-the CSR practices not always reflect the societal } \\
\text { views, more than that CSR addresses the } \\
\text { relationship between government and society }\end{array}$ & political theories \\
\hline $\begin{array}{l}\text { Vuta et al. } \\
(2019)\end{array}$ & $\begin{array}{l}\text {-CSR involves managers, stakeholders, civil } \\
\text { society, non-governmental organizations, the } \\
\text { government; a company should be considered as } \\
\text { a social institution that is social responsible. }\end{array}$ & $\begin{array}{l}\text { integrative } \\
\text { theories }\end{array}$ \\
\hline
\end{tabular}

Source: own representation based on the articles of the Romanian authors written in the period 20182019 in the Web of Science 
Most authors present CSR activities as an interdependent relationship between company and society: the company without society cannot exist and vice versa.

Most Romanian authors are based on integrative theories in their works. In essence, integrative CSR theories present how the corporation focuses on detecting, scanning, and responding to social requirements in a way that generates social legitimacy, greater social acceptance, and prestige.

The integrative approach argues that organizations need to integrate the social needs of the community, as they depend directly on society to continue their work and grow.

According to Dinu and Bunea (2019), companies that want to be sustainable are those that anticipate the future needs of society and they adapt their business to their needs.

CSR is the way in which management manages material and financial resources so as to be in accordance with environmental protection, serving the common good of the company and society (Marin-Pantelescu et al., 2019).

The papers of the authors, Bucur et al. (2019), Burlea-Schiopoiu et al. (2019), Cioca et al. (2019) and Saveanu et al. (2019) are based on integrative theory. Sustainability exists as long as there are demands from employees, from society, from stakeholders and others.

Simionescu and Dumitrescu (2018), Socoliuc et al. (2018) and Vuta et al. (2019) shows that CSR has a positive impact on stakeholders and supports voluntary, environmental, economic, community actions, all of which are ethical, economic, legal and discretionary. A company should be considered as a social institution that is socially responsible.

Farcane et al. (2019) and Obrad et al. (2018) are the authors whose papers are based more on ethical theories. The business environment and society are or should be determined by ethical values. Organizations should adopt social responsibility as an ethical obligation, among other considerations.

Stakeholder theory is closely linked to creating value for the entity and for stakeholders. The papers of the authors, Hategan et al. (2018) and Cosmulese et al. (2019), emphasize the theory of stakeholders, on a voluntary basis, CSR reporting was determined by stakeholders other than the state. The more stakeholders are interested in the organization's resources, the more important the organization is, the greater the effort of the organization's management to be able to meet the expectations of stakeholders.

Siminica et al. (2019) and Androniceanu A. (2019) have as main foundation in their papers the instrumental theories. The CSR concept is a strategic tool with which companies try to maximize profits while social and environmental issues. Managers want the company to have CSR shares only if they guarantee its profit.

The authors, Hategan et al. (2019) and Voinea et al (2019), present in their paper that CSR is closely linked to the politics and legislation of each country, the content of non-financial reports depends on government policies and cultures. Political theories address the relationship between corporations, governments and society.

Legitimacy emphasizes that organizations are constantly trying to ensure that they are perceived as operating within the binding and norms of the society in which they operate.

Cristache et al. (2019) and Stoica et al. (2019) take the view that in order to gain legitimacy, corporations have become more transparent and involved in social and environmental issues.

\section{Conclusion}

Given that all corporate social responsibility information is centralized in a non-financial report, it should be based on all six theories presented above. With these theories, nonfinancial reporting of companies would be transparent and credible to all stakeholders. Most authors present CSR activities as an interdependent relationship between company and society: the company without society cannot exist and vice versa. The most commonly 
used theories to define CSR are integrative theories, followed by political theories, ethical theories, legitimacy theory and stakeholder theory. CSR is seen as an approach of some actions, after which it will have to win both the company and the company, between the two, having a direct and reciprocal relationship.

The limit of this paper can be considered the small number of reviewed articles and a future direction of research can include several articles written by foreign Romanian authors and authors from other EU member states.

\section{Acknowlegments}

This work was cofinanced from the European Social Fund through Operational Programme Human Capital 2014-2020, project number POCU/380/6/13/125015 "Development of entrepreneurial skills for doctoral students and postdoctoral researchers in the field of economic sciences"

\section{References:}

Androniceanu, A., 2019. Social Responsibility, an Essential Strategic Option for a Sustainable Development in the Field of Bio-Economy. Amfiteatru Economic, 21(52), pp. 503-519. https://doi.org/10.24818/EA/2019/52/503

Bucur, M., Moica, S., Ardelean, S. and Otel, C.C., 2019. The importance of Corporate Social Responsibility among organisations in the Centre Development Region of Romania. Procedia Manufacturing, 32, pp. 309-317. https://doi.org/10.1016/i.promfg.2019.02.219

Carroll, A.B., 1991. The pyramid of corporate social responsibility: toward the moral management of organizational stakeholders. Business Horizons, 34(4), pp.39-48.

Burlea-Schiopoiu, A. and Mihai, L.S., 2019. An Integrated Framework on the Sustainability of SMEs. Sustainability, 11, 6026. https://doi.org/10.3390/su11216026

Cioca, L.I., Ivascu, L., Turi, A., Artene, A. and Gaman, G.A., 2019. Sustainable Development Model for the Automotive Industry. Sustainability, 11, 6447. https://doi.org/10.3390/su11226447

Cosmulese, C.G., Socoliuc, M., Ciubotariu, M.S., Mihaila, S. and Grosu, V., 2019. An empirical analysis of stakeholders' expectations and integrated reporting quality. Economic Research, 32(1), pp. 3963-3986. https://doi.org/10.1080/1331677X.2019.1680303

Cristache, N., Năstase, M., Petrariu, R. and Florescu, M., 2019. Analysis of Congruency Effects of Corporate Responsibility Code Implementation on Corporate Sustainability in BioEconomy. Amfiteatru Economic, 21(52), pp. 536-553. https://doi.org/10.24818/EA/2019/52/536

Dinu, V. and Bunea, M., 2019. The Corporate Social Responsibility of the Romanian Banking System. Finance, XXII(4), pp.119-132. https://doi.org/10.15240/tul/001/2019-4-008.

Dumitru, M., Dyduch, J., Gușe R.G., Krasodomska, J., 2017. Corporate Reporting Practices in Poland and Romania - An Ex-ante Study to the New Non-financial Reporting European Directive, Accounting in Europe, 14(3), pp. 279-304. https://doi.org/10.1080/17449480.2017.1378427

Farcane, N., Deliu, D. and Bureana, E., 2019. A Corporate Case Study: The Application of Rokeach's Value System to Corporate Social Responsibility (CSR). Sustainability, 11, 6612. https://doi.org/10.3390/su11236612

Fernando, S. and Lawrence, S., 2014. A theoretical framework for CSR practices: Integrating legitimacy theory, stakeholder theory and institutional theory. The Journal of Theoretical Accounting, 10.1, pp. 149-178. 
Friedman, M., 1970. The Social Responsibility of Business is to Increase its Profits. New York Times Magazine, Available: http://umich.edu/ thecore/doc/Friedman.pdf [10 January 2020].

Garriga, E. and Mele', D., 2004. Corporate Social Responsibility Theories: Mapping the Territory. Journal of Business Ethics, 53, pp. 51-71. https://doi.org/10.1023/B:BUSI.0000039399.90587.34

Geva, A, 2008. Three Models of Corporate Social Responsibility: Interrelationships between Theory, Research, and Practice. Business and Society Review, 113(1), pp. 1-41. https://doi.org/10.1111/i.1467-8594.2008.00311.x

Hategan, C.D. and Arraiano, I.G., 2019. The Stage of Corporate Social Responsibility in EUCEE Countries. European Journal of Sustainable Development, 8(3), pp. 340-353. https://doi.org/10.14207/ejsd.2019.v8n3p340

Hategan, C.D., Sirghi, N., Curea-Pitorac, R.I. and Hategan, V. P., 2018. Doing Well or Doing Good: The Relationship between Corporate Social Responsibility and Profit in Romanian Companies. Sustainability, 10, 1041. https://doi.org/10.3390/su10041041

Kerscher, A. and Schäfers, W., 2015. Corporate social responsibility and the market valuation of listed real estate investment companies. Zeitschrift für Immobilienökonomie, pp. 117-143; https://doi.org/10.1365/s41056-015-0005-7

Marin-Pantelescu, A., Tăchiciu, L., Căpușneanu, S. and Topor, D.I., 2019. Role of Tour Operators and Travel Agencies in Promoting Sustainable Tourism. Amfiteatru Economic, 21(52), pp. 654-669. https://doi.org/10.24818/EA/2019/52/654

Obrad, C. and Gherhes, V., 2018. A Human Resources Perspective on Responsible Corporate Behavior. Case Study: The Multinational Companies in Western Romania. Sustainability, 10, 726. https://doi.org/10.3390/su10030726

Obrad C., Petcu D., Gherhes V. and Suciu S., 2011., Corporate Social Responsibility in Romanian Companies - between Perceptions and Reality, Amfiteatru Economic, XIII(29), pp. 44-56;

Saveanu, T.G., Abrudan, M.M., Saveanu, S.M., and Matei, M.C., 2019. Predictors of social responsibility actions of SMEs in Romania, Journal of East European Management Studies, pp, 120-151. https://doi.org/10.5771/9783845298696

Scherer, A. G. and Palazzo, G., 2011. The New Political Role of Business in a Globalized World: A Review of a New Perspective on CSR and its Implications for the Firm, Governance, and Democracy. Journal of Management Studies, 48 (4), pp. 899-931. https://doi.org/10.1111/i.1467-6486.2010.00950.x

Siminica, M., Cristea, M., Sichigea, M., Noja, G.G. and Anghel, I., 2019. Well-Governed Sustainability and Financial Performance: A New Integrative Approach. Sustainability, 11, 4562. https://doi.org/10.3390/su11174562

Simionescu, L.N. and Dumitrescu, D., 2018. Empirical Study towards Corporate Social Responsibility Practices and Company Financial Performance. Evidence for Companies Listed on the Bucharest Stock Exchange. Sustainability, 10, 3141. https://doi.org/10.3390/su10093141

Socoliuc, M., Grosu, V., Hlaciuc, E. and Stanciu, S., 2018. Analysis of Social Responsibility and Reporting Methods of Romanian Companies in the Countries of the European Union. Sustainability, 10, 4662. https://doi.org/10.3390/su10124662

Stoica, D.A., Petrariu, I.R. and Chivu, R.G., 2019. NGOs perspective over CSR actions in an emerging economy. Proceedings of the International Conference on Business Excellence, pp. 933-944. https://doi.org/10.2478/picbe-2019-0082

Voinea, C.L., Fratostiteanu, C. and Romein, B., 2019. The Influence of Governance and Ownership on CSR Practices in Romania. European Journal of Sustainable Development, 8(3), pp. 313-325. https://doi.org/10.14207/ejsd.2019.v8n3p313 
Vuță, M., Cioacă, S.I., Vuţă, M. and Enciu, A., 2019. An Empirical Analysis of Corporate Social Responsibility Effects on Financial Performance for Romanian Listed Companies. Amfiteatru Economic, 21(52), pp. 607-622. https://doi.org/10.24818/EA/2019/52/607

\section{Bio-note}

Milu Nicoleta-Daniela is a PhD student at the Doctoral School of Economic Sciences and Business Administration from West University of Timisoara. In her doctoral research she focuses on the CSR activities and reporting and therefore this interest in addressing the theories underlying the CSR. 